\title{
Chemical evaluation of bitumen obtained from Agbabu and Loda in Ilaje Area, Ondo State, Nigeria
}

\author{
Aladekoyi, Gbenga ${ }^{1 *}$, Shakpo I. O. ${ }^{1}$ and Seyifunmi O. $E^{2}$ \\ ${ }^{1}$ Food Science and Technology Department, Rufus Giwa Polytechnic, Owo, Ondo State, Nigeria. \\ ${ }^{2}$ Science Laboratory Technology Department, Rufus Giwa Polytechnic, Owo, Ondo State, Nigeria. \\ *Corresponding author. Email: gbengu7@yahoo.com. Tel: +2348034651804.
}

Copyright @ 2016 Aladekoyi et al. This article remains permanently open access under the terms of the Creative Commons Attribution License 4.0, which permits unrestricted use, distribution, and reproduction in any medium, provided the original work is properly cited.

Received 7th July, 2016; Accepted 28th September, 2016

\begin{abstract}
ABTRACT: The chemical characteristics of bitumen influence its industrial values and its physical characteristics for road construction. There are vast deposits of bitumen in Agbabu and Loda in Odigbo and Irele area in Ondo State, Nigeria, for years unutilized. The evaluation of their chemical constituents with the imported bitumen, Raynolds Construction Company (RCC) revealed the concentration levels of sulphate content $(\mathrm{mg} / \mathrm{g})(252.30 \pm 0.01,172.10 \pm$ 0.02 and $167.50 \pm 0.01)$, sulphide content $(\mathrm{mg} / \mathrm{g})(186.80 \pm 0.01,180.40 \pm 0.01$ and $178.80 \pm 0.01)$, nitrogen content $(\mathrm{g} / 100 \mathrm{~g})(2.10 \pm 0.01$ and $3.06 \pm 0.02$ and $5.07 \pm 0.01)$ obtained from Agbabu, Loda and RCC bitumen respectively. The Total Petroleum Hydrocarbon and Polycyclic Aromatic Hydrocarbon from the three sources (Agbabu, Loda and RCC) were determined by Gas chromatography (GC) and Gas chromatography/Mass Spectroscopy (GC/MS) Varian Chromapack (SATURN 2000). The results obtained were; TPH (mg/kg) 224622.00, 271271.00 and 91479.00, PAH $(\mathrm{mg} / \mathrm{kg}) 2941.00,500.00$ and 166.6 respectively. The results revealed that Agbabu bitumen has higher values than the rest in terms of its $\mathrm{TPH}$ and $\mathrm{PAH}$.
\end{abstract}

Key wards: Aromatics, bitumen, chemical concentration, hydrocarbons, petroleum.

\section{INTRODUCTION}

Bitumen is a mixture of organic substances that are highly viscous, black, sticky and soluble in most organic solvents. It composed primarily of highly condensed polycyclic aromatic hydrocarbons, heterocyclic compounds and several heavy metals such as nickel, vanadium, lead, chromium, mercury arsenic, selenium and other toxic elements (Wikipedia, 2007). Bitumen is a thick, black and visco-elastic material consisting of a complex mixture of saturate, aromatic, resin and asphaltene with some trace metals such as iron, nickel and vanadium. Bitumen is known to contain heterocyclic compounds having composed largely of about 80 percent by weight of carbon, 10 per cent by weight of hydrogen, 6 per cent by weight of sulphur, small amounts of oxygen and nitrogen. It is substantially soluble in some solvents such as carbon disulphide and trichloroethylene and become molten when heated (Zhang et al., 2009; ASTM, 2009). It is the residual bottom fraction obtained by fractional distillation of crude oil. It is widely believed that bitumen is formed from the remains of ancient microscopic algae and other death living things. These organisms died and their remains were deposited in the mud on the bottom of the ocean or lake when they once lived. Under the influence of sufficient heat and pressure, the algae now transformed into materials such as bitumen or petroleum products. Bitumen is also found in meteorites, arched rocks, copper, zinc mineralizations, and caves. It is possible that bitumen is a primordial material formed during the creation of the earth and reworked by bacteria that consume hydrocarbons. Naturally, bitumen exists in two main forms: either as pare bitumen accumulated down-deep below the earth surface or outcrops as oil impregnated sand, which is commonly referred to as tar sand or oil sand (Wikipedia, 2007).

Bitumen was first discovered in Nigeria in 1910. The first bitumen well NBC-7 was drilled at Agbabu in Ondo State in the South Western part of Nigeria. Some studies have been carried out on the Nigerian bitumen and Agbabu Bitumen deposit such as multi elemental analysis 
(Adebiyi et al., 2006), environmental impact assessment of bitumen exploitation on animal resources of Ode-Irele (Lameed and Ogunsusi, 2002), compositional analysis of the oil component of the Nigerian bitumen (Oderinde and Olanipekun, 1991), Distribution of Polycyclic Aromatic hydrocarbons in soils and water from the vicinity of Agbabu bitumen field (Olajire et al., 2007), and solvent extraction of vanadium from Nigerian bitumen (Oguntimehin and Ipinmoroti, 2007).

\section{Basic Composition of Bitumen}

Bitumen can be characterized by their chemical composition and it is bitumen's chemical properties that determine its physical properties. Therefore, a basic understanding of bitumen Chemistry can help one understand how and why it behaves the way it does. Bitumen Chemistry can be described on molecular level as well as on intermolecular (microstructure) level. On molecular level, bitumen is a mixture of complex organic molecules that ranges in molecular weight from several hundreds to thousands. Although, these molecules exhibit certain behavioral characteristics at the intermolecular level of the bitumen's microstructure (Robertson et al.,1991).

\section{Industrial Applications of Bitumen}

Bitumen is primarily used for paving roads. Its other uses include production of waterproofing products e.g. roofing felt used for sealing roofs. It is also the prime feed stock for petroleum production from tar sands. The presence of relatively large amount of naphthenes, aromatics hydrocarbons and asphaltenes, that are similar to conventional oils, make tar sand a very useful alternative source of petroleum hydrocarbons. The extract from bitumen are very rich in aromatics, this makes it a suitable feedstock for petrochemical industries (Lurgi, 1987; Adegoke et al., 1980b). In crude oils, the methyl derivative is the most abundant compound, being present in greater quantities than the parent alicyclic compound (Speight, 1999).

The need for this research arose because no study has been reported on some of the inorganic component like sulphur, sulphate and nitrogen content on Agbabu in Odigbo LGA and Loda in Irele LGA catchment zone in Ondo due to their vast deposit in these areas by random sampling to have a good representation and their importance over Raynolds Construction Company (RCC) bitumen. The possibility of obtaining other chemical products for industrial purposes by looking closely into their molecular weights in terms of their Alphatates and Aromatics structures by Gas Chromatography (GC) and Gas Chromatography / Mass Spectroscopy (GC/MS) are put into consideration.

Hence, this present work aims to achieve the following objectives: To characterize extracted bitumen from Agbabu and Loda areas in Odigbo and Irele Local Government and imported bitumen (RCC) through; the determination of Saturates and Aromatics properties by Gas Chromatography (GC) and Gas Chromatography/ Mass Spectroscopy (GC/MS) for their chemical Characteristics and the employment of their products in commercial quantities for Industrial purposes and Correlate the properties of the different bitumen by determine their chemical properties such as Sulphate, Nitrogen and Sulphide contents.

\section{MATERIALS AND METHODS}

\section{Sample collection}

Raw bitumen samples were obtained by random sampling from agbabu and Loda deposited site in Odigbo and Irele Local Government Area, Ondo State, Nigeria (Figure 1), while the Raynolds Construction Company bitumen (RCC) was obtained from their construction site in Lagos-Ibadan Express way.

\section{Extraction method}

The Extraction method adopted was Sohxlet extraction method using acetone as solvent. Ten $(10 \mathrm{~g})$ of the bitumen sample $\left(w_{1}\right)$ was added to already weighed thimble $\left(w_{2}\right)$ and placed in the Soxhlet apparatus fixed with boiling flask which was filled to three quarter (3/4) with acetone and heated by heating mantle. Continuous extraction was done until a clear solvent was observed at the thimble containing the sample. The thimble and the remaining materials from the sample, which is mainly sand content was obtained ( $\left.w_{3}\right)$. The bitumen content was obtained by distilling the acetone from the bitumen acetone mixtures in the boiling flask.

\section{Parameters determined}

Total sulphide and sulphate contents were determined by Spectrophotometry method (Turbidometric and Colorimetric Method) described by Ademoroti, 1996 and Nitrogen content by Kjeldhal method (AOAC,2000). The determination of Saturates (Total Petroleum Hyrocarbon) and Aromatics (Polycyclic Aromatic Hydrocarbon) properties by Gas Chromatography(GC) and Gas Chromatography/Mass Spectroscopy (GC/MS) was from Thermosteel Nigeria Limited, Warri, Nigeria.

\section{Total Sulphate Concentration (Turbidometric Method)}

The sample was digested by weighing $2 \mathrm{gm}$ of it into a Kjeldahl flask. At pH 3.0, $5 \mathrm{ml}$ of concentrated $\mathrm{HNO}_{3}$ was added and evaporated. $10 \mathrm{ml}$ of $70 \% \mathrm{HClO}_{4}$ was added 


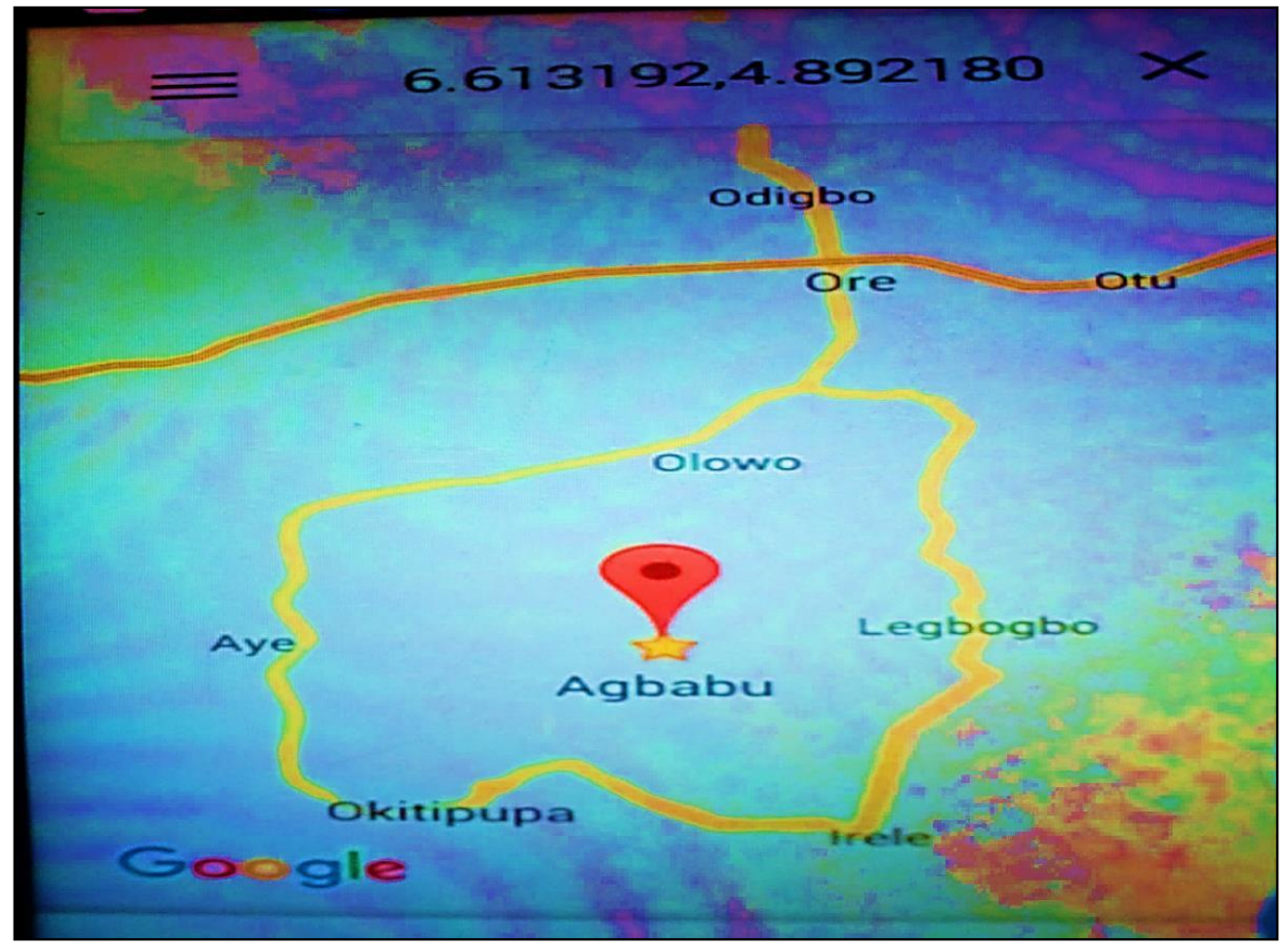

Figure 1. Map of Agbabu and Loda Area in Ilaje, Ondo State, Njgeria.

with few boiling ships. It was heated strongly until a clear solution was observed. $6 \mathrm{M} \mathrm{NaOH}$ was added to neutralize it. It was made up to $100 \mathrm{ml}$ with distilled water in volumetric flask. $5 \mathrm{ml}$ of conditioning reagent $(50 \mathrm{ml}$ glycerol, $30 \mathrm{ml}$ concentrated $\mathrm{HCl}, 300 \mathrm{ml}$ distilled water, $100 \mathrm{ml} \mathrm{95 \%} \mathrm{ethanol} \mathrm{and} 75 \mathrm{~g} \mathrm{NaCl}$ ) was added. On stirring, a spoonful of Barium chloride crystal was added and stirred constantly for one minute. It was poured into the absorbance cell and the absorbance of the turbidity produced was taken by UV Spectrophotometer at 425 $\mathrm{nm}$. Absorbance of the Blank and serial dilution of primary standard sulphates stock solution were obtained at the same temperature. The graph obtained from the standard was used to obtain the concentration in milligram per gram $(\mathrm{mg} / \mathrm{l})$.

\section{Total Sulphide Concentration (Colorimetric Method)}

The sample was digested by weighing $2 \mathrm{gm}$ of it into a Kjeldahl flask. At pH 3.0, $5 \mathrm{ml}$ of concentrated $\mathrm{HNO}_{3}$ was added and evaporated. $10 \mathrm{ml}$ of $70 \% \mathrm{HClO}_{4}$ was added with few boiling ships. It was heated strongly until a clear solution was observed. $6 \mathrm{M} \mathrm{NaOH}$ was added to neutralize it and it was made up to $90 \mathrm{ml}$ with distilled water. $5 \mathrm{ml}$ of test solution was added $(0.5 \%$ of mixed 25 $\mathrm{ml} \mathrm{p-amino} \mathrm{dimethyl} \mathrm{aniline} \mathrm{stock} \mathrm{with} 975 \mathrm{ml}$ of $91+1 \mathrm{H}_{2} \mathrm{SO}_{4}$ ). It was stirred very well and $1 \mathrm{ml}$ of freshly prepared $\mathrm{FeCl}_{3}$ solution was added and methylene blue color developed. It was diluted to $100 \mathrm{ml}$. It was poured into the absorbance cell and the absorbance was taken by UV Spectrophotometer at $745 \mathrm{~nm}$. Absorbance of the blank and the serial dilution of primary standard sulphide stock solution were obtained at the same temperature. The graph obtained from the standard was used to obtain the concentration in milligram per gram ( $\mathrm{mg} / \mathrm{l})$.

\section{Nitrogen Concentration (Kjeldhal Method)}

One gram $(1 \mathrm{~g})$ of the sample was weighed into $250 \mathrm{ml}$ kjeldhal flask. One tablet of kjeldhal catalyst was added and $10 \mathrm{ml}$ of concentrated $\mathrm{H}_{2} \mathrm{SO}_{4}$. It was heated gently for 15 minutes and rapidly at high temperature of $35^{\circ} \mathrm{C}$ until a clear or light green or grey colour was observed. The solution was allowed to cool and diluted to $100 \mathrm{ml}$ with distilled water. $5 \mathrm{ml}$ of $2 \%$ boric acid was put into 100 $\mathrm{ml}$ beaker. 2 to 3 drops of mixed indicator were added and put at the tip of the condenser which has been fixed with the Markham distiller. $5 \mathrm{ml}$ of the diluted digest was put into the Markham, followed by $10 \mathrm{ml}$ of $40 \% \mathrm{NaOH}$ and the tap closed. It was steam distilled until $50 \mathrm{ml}$ of the distillate was recovered in the beaker at the tip of the condenser. The distillate was then titrated with $0.01 \mathrm{M}$ $\mathrm{HCl}$ until the colour changed to give the end point. The same process was carried out with the blank (distilled water used for dilution).

Equation for the reaction: 
Table1. Results of some chemical properties of bitumen obtained from Agbabu, Loda and Raynold Construction Company (RCC).

\begin{tabular}{lccc}
\hline Parameters & Agbabu & Loda & RCC \\
\hline Sulphate $(\mathrm{mg} / \mathrm{g})$ & $252.30 \pm 0.01$ & $172.10 \pm 0.02$ & $167.50 \pm 0.01$ \\
Sulphide $(\mathrm{mg} / \mathrm{g})$ & $186.80 \pm 0.01$ & $180.40 \pm 0.01$ & $178.80 \pm 0.01$ \\
Nitrogen $(\mathrm{g} / 100 \mathrm{~g})$ & $2.10 \pm 0.01$ & $3.06 \pm 0.02$ & $5.07 \pm 0.01$ \\
\hline
\end{tabular}

$\pm S D$ values of triplicate analysis.

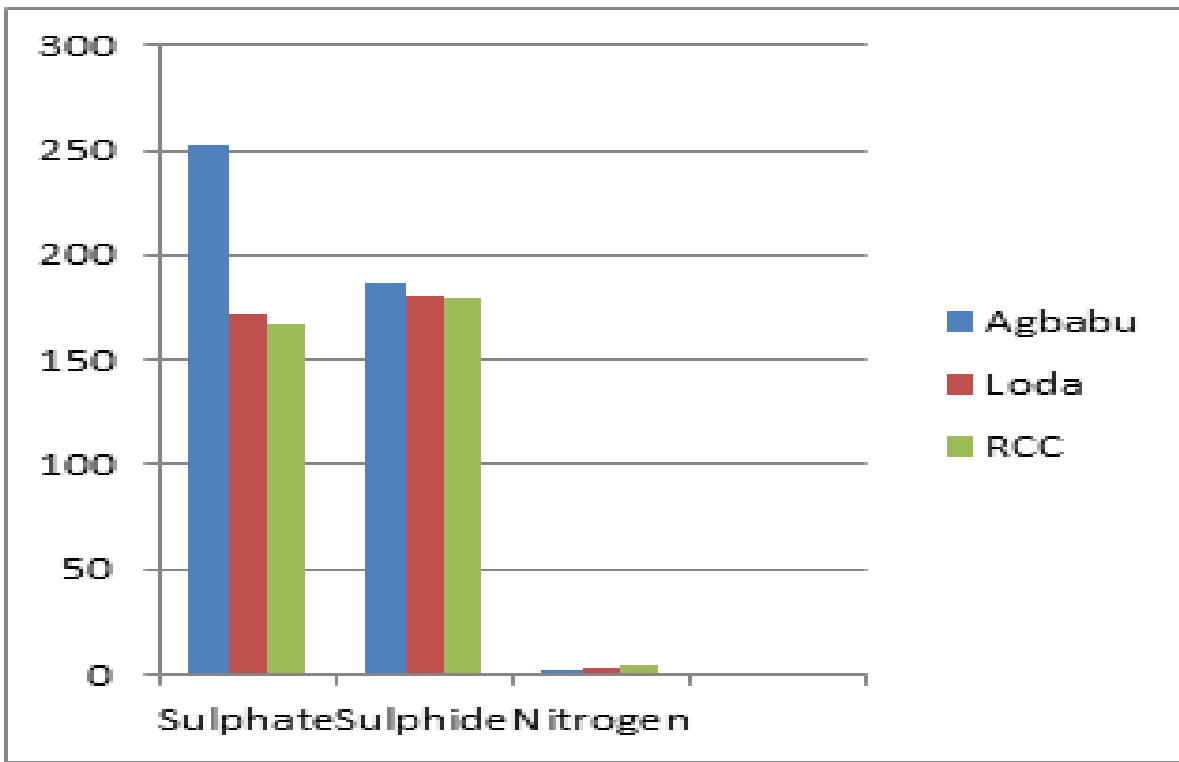

Figure 2. Bar Chart for chemical compositions of Agbabu, Loda and RCC bitumen.

Digestion $-\mathrm{H}_{2} \mathrm{SO}_{4}+2 \mathrm{NH}_{3} \rightarrow\left(\mathrm{NH}_{4}\right)_{2} \mathrm{SO}_{4}$

Distillation - $\left(\mathrm{NH}_{4}\right)_{2} \mathrm{SO}_{4}+2 \mathrm{NaOH} \rightarrow \mathrm{Na}_{2} \mathrm{SO}_{4}+2 \mathrm{NH}_{3}+$ $2 \mathrm{H}_{2} \mathrm{O}$

$$
\mathrm{NH}_{3}+\mathrm{H}_{3} \mathrm{BO}_{3} \rightarrow \mathrm{NH}_{4}+\mathrm{H}_{2} \mathrm{BO}_{3}^{-}
$$

Titration $-\mathrm{NH}_{4}{ }^{+}+\mathrm{H}_{2} \mathrm{BO}_{3}{ }^{-}+\mathrm{HCl} \rightarrow \mathrm{NH}_{4} \mathrm{Cl}+\mathrm{H}_{3} \mathrm{BO}_{3}$

$\% \mathrm{~N}=\frac{(\mathrm{t} 1-\mathrm{t} 2) \times 0.01 \times 0.014 \times 100 \times 100}{\text { sample wt } \times 5}$

Where $t 1$ is the titre value of the sample and $t 2$ is the titre value of the blank.

\section{RESULTS AND DISCUSSION}

The Chemical constituents from Agbabu, Loda and RCC bitumen were indicated in Table 1. Sulphate concentrations evaluated in $\mathrm{mg} / \mathrm{g}$ had values of $252.30 \pm$ $0.01,172.10 \pm 0.02$ and $167.50 \pm 0.01$, sulphide concentrations in $\mathrm{mg} / \mathrm{g}$ had values of $186.80 \pm 0.01$, $180.40 \pm 0.01$ and178.80 \pm 0.01 for Agbabu, Loda and
RCC bitumen, respectively. Agbabu bitumen has the highest sulphates concentration compared to bitumen obtained from loda and RCC. High sulphates concentration may result into maximum industrial applications in Agbabu bitumen over Loda and RCC bitumen, because sulphates concentration has many chemical applications. The sulphide concentrations showed no significant difference in Agbabu, loda and RCC (Figure 2) and the values ranged between 178 to $186 \%$ with the minimum in RCC bitumen and maximum in Agbabu bitumen. The compounds of sulhpur can lead to increase in the average boiling point as the fraction increases according to Gruse \& Stevens, (1960), but it is not indicative of a high degree of contamination. The results obtained for the three samples in terms of sulphide concentration indicated that their boiling points are relatively close to one another. The nitrogen contents in $\mathrm{g} / 100 \mathrm{~g}$ are $2.10 \pm 0.01,3.06 \pm 0.02$ and $5.07 \pm 0.01$ ( 2 to $5 \%$ range) for Agbabu, Loda and RCC bitumen respectively (Table 1 ). Agbabu bitumen has the lowest nitrogen content compared to Loda with the higher value (Figure 2). The high sulphates and sulphide concentration may be of advantage in petrochemical industries. Nitrogen compounds are undesirable in crude 
Table 2. Results of saturates as Total Petroleum Hydrocarbon (TPH) and Polycyclic Aromatic Hydrocarbon (PAH) of bitumen obtained from Agbabu, Loda and Raynolds Construction Company (RCC).

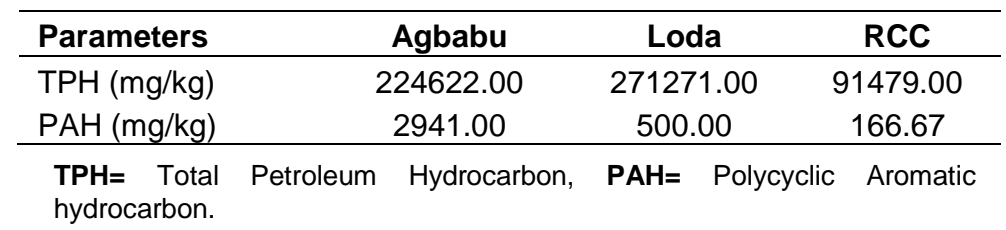

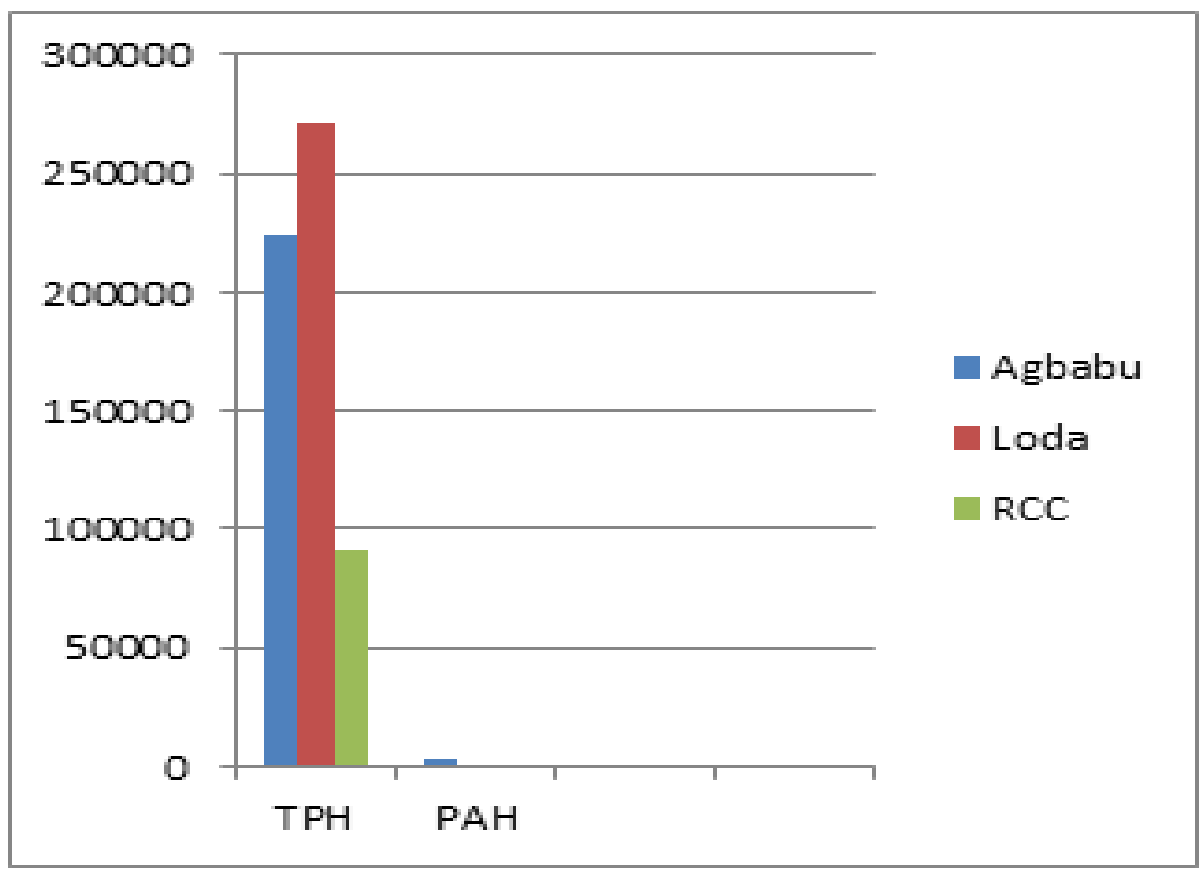

Figure 3. Bar chart for TPA and PAH compositions of Agbabu, Loda and RCC bitumen.

oils as they are responsible for poisoning of catalyst and the formation of gums in fuel oils (Siefet,1969). The low percentage of nitrogen in Agbabu bitumen indicated that the level of contaminants and formation of gum are lesser than that of Loda and RCC bitumen. Table 2 revealed the results from both saturates (Total Petroleum Hydrocarbon) and aromatics (Polycyclic Aromatic Hydrocarbon) of bitumen obtained from Agbabu, Loda and RCC respectively. The values obtained for TPH $(\mathrm{mg} / \mathrm{kg})$ were 224622.00, 271271.00 and 91479.00 for Agbabu, Loda and RCC respectively. Highest value was recorded in Loda bitumen (Figure 3). This showed that Loda bitumen with maximum value $(271271.00 \mathrm{mg} / \mathrm{kg}$ ) are rich in heterocyclic hydrocarbons, a straight chain organic compounds with minimum value obtained in RCC bitumen $(91479.00 \mathrm{mg} / \mathrm{kg} 0$. PAH $(\mathrm{mg} / \mathrm{kg})$ were 2941.00, 500.00 and 166.67 for Agbabu, Loda and RCC respectively. Highest value was recorded in Agbabu bitumen compared to other values (Figure 3 ). The results for TPH and PAH were obtained from the peak values (voltage/retention time) of numbers of carbons. Aromatic compounds have many industrial and pharmaceutical applications and the maximum utilization can be achieved in Agbabu bitumen due to its highest concentration $(2941.00 \mathrm{mg} / \mathrm{kg}$ ) when compared to Loda and RCC bitumen. The TPH $(\mathrm{mg} / \mathrm{kg})$ indicated the multiplication of concentration of fraction from graph (C), volume of extract used $(\mathrm{V})(\mathrm{ml})$ and dilution factor (D) (if any) to the $\mathrm{kg}$ of bitumen sample used (B) to1/100 while the PAH $(\mathrm{mg} / \mathrm{kg})$ indicated the multiplication of the concentrated amount $(\mathrm{C})$ and volume of extract $(\mathrm{V})(\mathrm{ml})$ to the retention time $\left(R_{t}\right)$ and $\mathrm{kg}$ of bitumen sample $(B)$. These are as shown below:

$\mathrm{TPH}(\mathrm{mg} / \mathrm{kg})=$

$\underline{\text { Con. on fraction from graph } x \text { volume of extract }(\mathrm{ml}) \times \mathrm{D} \text {. factor }}$ $\mathrm{Kg}$ of sample

$\mathrm{PAH}(\mathrm{mg} / \mathrm{kg})=$ concentration amount/Rf $x$ volume of extract $(\mathrm{ml})$ $\mathrm{Kg}$ of sample 


\section{Conclusion}

The results obtained from bitumen from Agbabu, Loda and RCC for the sulphates, sulphide and nitrogen concentrations in correlation with their chemical properties revealed many industrial applications. Agbabu bitumen showed reasonable values for industrial applications and road construction than values obtained from the rest. The TPH value was higher in Loda bitumen, but its industrial application may not be economical due to low bitumen to sand percentage (46.5\%) during extraction of raw sample compared to bitumen to sand content in Agbabu (79.8\%). The lower value in RCC may be due to the processing method adopted by the manufacturer to suit their purpose.

\section{Recommendation}

Under more comprehensive and technical examination, Agbabu bitumen can be employed for road construction and used as feedstock for petrochemical industries. It is economical when compared to bitumen obtained from Loda and RCC bitumen.

\section{CONFLICT OF INTEREST}

The authors declare that they have no conflict of interest.

\section{REFERENCES}

Adebiyi, F. M., Asubiojo, O., I., \& Ajayi T. R. (2006). Multielemental analysis of Nigeria bitumen by TXRF Spectrometry and the physical constants characterization of its hydrocarbon components. Fuel 85(3), 396-400.

Adegoke, O. S., Ako, B. D., \& Enu, E. I. (1980). Geotechnical investigation of the Ondo State bituminous sands. Vol.1, Geology and Reserves Estimate. Geological Consultancy Unit, Department of Geology, Obafemi Awolowo University, Ile-Ife. P. 56

Ademoroti C. M. A. (1996). Standard Methods for Water and Effluents Analysis. Fludex Press Ltd, Ibadan, Pp. 55-96.

AOAC (2000). Official Methods of Analysis. Association of Official analytical chemist $15^{\text {th }}$ edition, Washington DC, USA.
ASTM International (ASTM) D 4124 - 01, (2009). Standard Test Methods $f$ or Separation of Asphalt into Four Fractions. Annual Book of ASTM Standards, Road and Paving Materials; Vehicle Pavement Systems, 04.03, West Conshohocken, Pennsylvania.

Gruse, W. A., \& Steven, D. K. (1960). Chemical Technology of Petroleum. 3rd edn. Mc. Graw-Hill Book Co. Inc. New York. P. 501.

Lameed, G. A, Ogunsusi K. (2002). Environmental impact assess of bitumen exploitation on animal resources of Ode Irele Forest area. Africal J. of Live- stock Ext .1, 15-21

Lurgi, R. (1987). Distillation test on tar sand from Ondo State, Nigeria. Essen. Pp. 1-8.

Oderinde, R. A, \& Olanipekun, E. O. (1991). Composition analysis of the oil component of the Nigerian bitumen. J. Afr. Earth Sci 12(3), 483-487.

Oguntimehin, I, \&. Ipinmoroti K.O. (2007). Solvent extraction of vanadium from Nigerian bitumen using Tributylphosphate. $J$. Appl. Sci. 7(24), 4028-4031.

Olajire, A. A., Alade, O. A., Adeniyi, A. A., Olabemiwo, M. O. (2007). Distribution of Polycyclic Aromatic Hydrocarbons in surface soils and water from the vicinity of Agbabu bitumen field of Southwestern Nigeria. J. Environ. Sci. Health, 42(8), 1043-1049.

Speight, J. G. (1999). The Chemistry and Technology of Petroleum. Marcel Dekker INC. New York. P. 5.

Robertson, M. M., Maclead, K., \& Luk, J. (1991). Rheological Properties and Structure of Bitumen. Journal of Geotechnical and Geoenvironmental engineering, 137(4), 44.

Zhang, J. I., Junlong, W., Yiqian, W., Wenxiu, S., \& Yunpu, W. (2009). Thermal Behaviour and Improved Properties of SBR and SBR/Natural Bitumen Modified Bitumens. Iranian Polymer Journal, 18 (6), 465-478.

Wikipedia free encyclopedia (2007). Canada's oil sands opportunities and challenges. National Energy Board. 